Weapons plan gives United Nations key role

Geoff Brumfiel, Washington

Arms-control specialists have proposed a sweeping plan to put the brakes on the international spread of nuclear weapons.

The Carnegie Endowment for International Peace, a Washington-based thinktank, unveiled its plan to government officials and other specialists at its non-proliferation conference in Washington on 21 June.

The proposal, which is put forward as existing non-proliferation arrangements come under pressure in Iran, North Korea and elsewhere, relies on the United Nations taking a more proactive role in preventing the spread of nuclear weapons and materials.

Current approaches to non-proliferation are not working, says Joseph Cirincione, director of the Carnegie Non-Proliferation Project and a co-author of the plan. "We hope this report will build an expert and political consensus around a new strategy," he adds. But critics say that the draft report is a hotchpotch of sometimes conflicting ideas that cannot easily be combined.

"In my view, this could be the beginning of a much needed discussion on non-proliferation and security," Mohamed ElBaradei, director-general of the International Atomic Energy Agency, told the meeting.

Opinion in the United States is sharply divided between those who support a system of arms control based on international treaties, and those who think that the United States should use its military and political power to stop the spread of nuclear weapons.

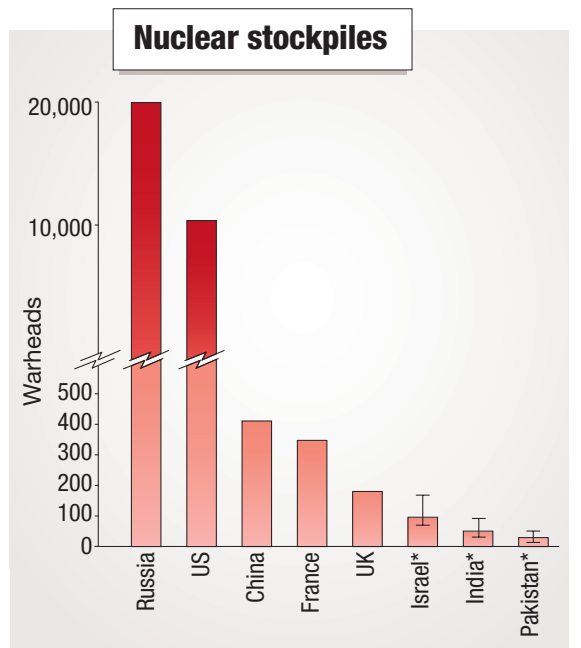

*These countries are thought to have enough nuclear material for these weapons; the actua number of weapons is unknown

The Carnegie plan outlines five basic duties for nations. They must work to ensure that there are no new nuclear-weapons states, secure existing stockpiles of nuclear materials, stop illegal transfers of nuclear-related technology, commit to resolve conflicts in their regions, and diminish the overall number of nuclear weapons. Current estimates put the number of nuclear weapons worldwide at more than 30,000 , with the majority in Russia and the United States (see graph).

The plan calls for "universal compliance" from all nations, whether they are party to existing nuclear-weapons treaties or not. Any nation participating in the illegal transfer of technology, or actively pursuing its own programme to build a bomb, would be subject to sanctions or military intervention from the United Nations Security Council.

"There is a lot of good stuff in the report," says Michael Levi, an arms-control expert at the Brookings Institution in Washington. But he adds that some of the ideas will be tough to sell. A proposal to halt the production of weapons-grade uranium worldwide, for example, is unlikely to go down well in Europe, where nuclear power plants produce such material as a by-product.

Others object to sections of the report calling for the United States and Russia to stop nuclear testing and to halt research on new nuclear weapons. "Developing new types of nuclear weapon may be essential to deterrence," says Baker Spring, a defence analyst at the Heritage Foundation in Washington.

"A lot of ideas that are not very comfortable alongside each other have been stuffed into this report," says Paul Robinson, director of Sandia National Laboratories in Albuquerque, New Mexico, the main US nuclearweapons engineering lab. Among them, he says, is a proposal to allow Pakistan, India and Israel to join the nuclear non-proliferation treaty. This would reward them for defying the 1970 treaty, Robinson contends.

Cirincione says that he and his coauthors welcome different views on the subject, and will release a "significantly different" final plan in December.

\title{
Santa Cruz brush-off leaves artists in a different class
}

Jonathan Knight, San Francisco

An unusual and highly regarded programme to train scientific illustrators at the University of California (UC) has suffered a setback under state budget cuts. Over the summer it will move from the university's campus in Santa Cruz to its less prestigious extension programme nearby.

The switch illustrates how the less wellknown aspects of the scientific enterprise suffer first in lean times. "It's an amazing programme. It has produced brilliant artists," says Malcolm Margolin, a publisher of natural-history books in Berkeley, California. "But illustration is a neglected art in the age of photography."

Science illustrators occupy a niche in science communication that photography cannot fill. For instance, in drawing wildlife they can highlight several features of an animal, such as the details of a feather and the shape of an eye, that a photographer would have difficulty capturing in a single image. Illustrators can also render extinct creatures - the four-winged dinosaur on the cover of Nature on 23 January 2003, for example, was drawn by a graduate of the Santa Cruz programme.

Illustrators can also draw conceptually difficult processes that are too small to see directly, such as protein synthesis or chemical catalysis. They can produce vibrant landscapes from the murky footage returned by submarines in deep ocean trenches or the transmissions of a martian lander. Their drawings illustrate textbooks, museum exhibits, scientific papers and popular magazines. But the Santa Cruz programme is one of only a handful to train such people.

The programme's move was forced by state budget cuts, says David Kliger, dean of physical and biological sciences at UC
Santa Cruz. It was more expensive than other programmes because it retained three faculty members to teach only ten students. "It was a luxury we couldn't afford right now," he says.

Although Kliger says he does not expect the move to adversely affect the programme, former students worry that reduced access to campus libraries and labs may be a problem. "It was important to be on campus," says 2004 programme graduate Amadeo Bachar, now an intern at National Geographic in Washington. "At least half of us were working with research professors."

The move may already have cost the programme some applicants. Only 20 applications had arrived by the 15 May deadline, less than half the usual number, says Andrea Michels, manager of the science-communication department. 